\title{
Synthesis and antioxidant evaluation of some new sulphadimidine incorporating thiophene moiety
}

\author{
Moustafa Ahmed Gouda a,b,*, Hadeer Fakhr Eldien a, \\ Margret Mansour Girges a and Moged Ahmed Berghot a \\ a Chemistry Department, Faculty of Science, Mansoura University, Mansoura 35516, Egypt \\ b Department of Chemistry, Faculty of Science and Arts, Taibah University, Ulla, 41411, Kingdom of Saudi Arabia \\ *Corresponding author at: Chemistry Department, Faculty of Science, Mansoura University, Mansoura 35516, Egypt. \\ Tel.: +2.050.6432235. Fax: +2.050.2246781. E-mail address: dr mostafa chem@yahoo.com (M.A. Gouda).
}

\section{ARTICLE INFORMATION}

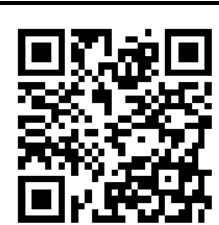

DOI: 10.5155/eurjchem.5.4.595-600.1106

Received: 11 June 2014

Received in revised form: 12 July 2014

Accepted: 121 July 2014

Online: 31 December 2014

\section{KEYWORDS}

\section{Thiophene}

Pyrimidine

Sulphadimidine

Cyanoacetamide

Cyanoacetylation

Antioxidant evaluation

\section{Introduction}

Sulphadrugs have attracted special attention from their therapeutic importance as they were used against a wide spectrum of bacterial aliments [1]. Some sulphadrugs have been used in the treatment of cancer, malaria, leprosy and tuberculosis [2,3]. Moreover, many thiophene derivatives were reported to exhibit different biological properties, such as A1 adenosine receptor, allosteric enhancers [4,5], inhibitors of Human Leukocyte Elastase [6,7], antitumor [8], virucides, virostatic agent, [9], antitumor and anti-HIV activities [4]. Different methods were reported for the syntheses of azo sulphadrugs [10-15].

Considering the facts that nearly all of the classes of heterocyclic compounds are biologically active and as a part of our continuous efforts towards the development of more potent antioxidant agents [16-20]. It was thought of interest to combine the above mentioned boilable rings together in a molecular framework to investigate the additive effect of these rings towards antioxidant activity.

\section{Experimental}

\subsection{Instrumentations}

All melting points are determined on Gallenkamp electric melting point apparatus (uncorrected). Thin layer chromatography (TLC) analysis was carried out on silica gel $60 \mathrm{~F}_{254}$ precoated aluminum sheets. The IR spectra were recorded $(\mathrm{KBr})$ on a Mattson 5000 FTIR Spectrophotometer at the Microanalytical Unit, Faculty of Science, Mansoura University. The ${ }^{1} \mathrm{H}$ NMR spectra were determined on a Varian XL $200 \mathrm{MHz}$ at the Microanalytical Center, Faculty of Science, Cairo University, Egypt using DMSO- $d_{6}$ as solvents and tetramethylsilane as internal standard. The mass spectra (EI) were recorded on $70 \mathrm{eV}$ with Kratos MS equipment at the Microanalytical Center, Cairo University, Egypt. Elemental analyses ( $\mathrm{C}, \mathrm{H}$ and $\mathrm{N}$ ) were carried out at the Microanalytical Center of Cairo University, Egypt. Biological activities were carried out at Pharmacognosy Department, Faculty of Pharmacy, Mansoura University, Mansoura, Egypt.

\subsection{Synthesis}

2.2.1. Synthesis of 2-cyano-N-(3-cyano-4-phenylthiophen-2yl)acetamide (4)

A mixture of compound 2 (2.8 g, $14 \mathrm{mmol})$ and 3-(3,5dimethyl-1H-pyrazol-1-yl)-3-oxopropanenitrile (3) (2.39 g, 14 


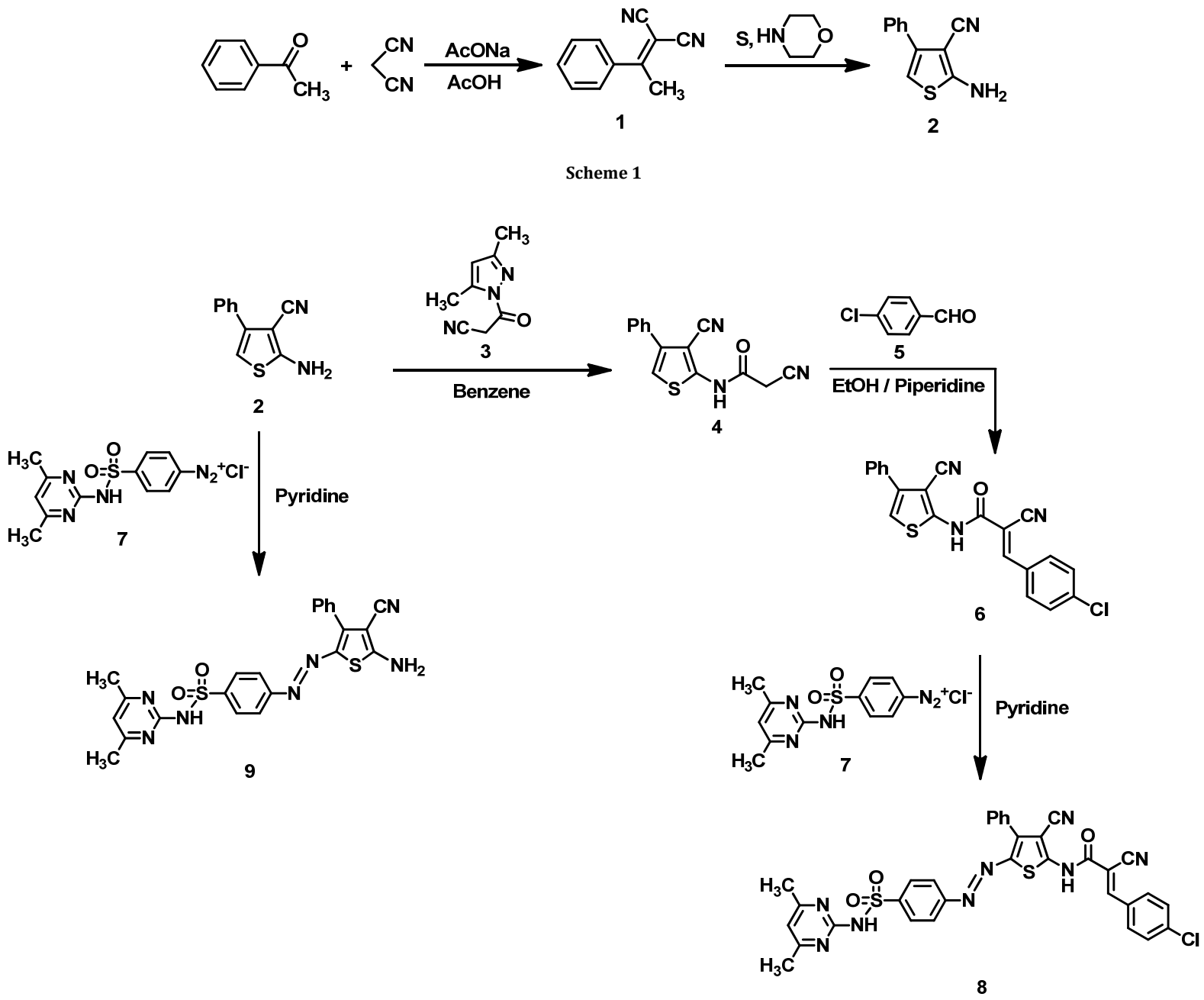

Scheme 2

mmol) in benzene $(20 \mathrm{~mL})$ was refluxed for $8 \mathrm{~h}$. The solvent was evaporated under vacuum and the residue was crystallized form ethanol to give carboxamide 4 (Scheme 1 and 2). Color: White powder. Yield: $44 \%$. M.p.: $230-232{ }^{\circ} \mathrm{C}$. FT-IR (KBr, v, cm1): $3212(\mathrm{NH}), 2242,2217$ (2CN), 1693 (CO). ${ }^{1} \mathrm{H}$ NMR (200 MHz, DMSO- $\left.d_{6}, \delta, \mathrm{ppm}\right): 4.24\left(\mathrm{~s}, 2 \mathrm{H}, \mathrm{CH}_{2}\right), 7.60-8.42\left(\mathrm{~m}, 6 \mathrm{H}, \mathrm{Ar}-\mathrm{H}, \mathrm{C}_{5}-\right.$ $\mathrm{H}$ of thiophene), 11.12 (brs., 1H, NHCO). MS (EI, $m / z$ (\%)): 269 $\left(\mathrm{M}^{+}+2,1.3\right), 268\left(\mathrm{M}^{+}+1,3.6\right), 267\left(\mathrm{M}^{+}, 18.7\right), 225(0.3), 201$ (14.2), 200 (100.0), 172 (10.4), 168 (1.7), 155 (12.6), 146 (1.2), 128 (3.9), 93 (1.8), 74 (0.5). Anal. calcd. for $\mathrm{C}_{14} \mathrm{H}_{9} \mathrm{~N}_{3} \mathrm{OS}$ (267.05): C, 62.91; H, 3.39; N, 15.72\%. Found: C, 62.88; H, 3.45; N, 3.34\%.

\subsubsection{Synthesis of (E)-3-(4-chlorophenyl)-2-cyano- $\mathrm{N}$-(3- cyano-4-phenylthiophen-2-yl) acrylamide (6)}

A mixture of compound 4 (1.3 g, $5 \mathrm{mmol})$, piperidine $(0.2$ $\mathrm{mL})$ and $p$-chlorobenzaldehyde $(0.7 \mathrm{~g}, 5 \mathrm{mmol})$; in ethanol (15 $\mathrm{mL}$ ) was stirred at $80^{\circ} \mathrm{C}$ for $1 \mathrm{~h}$. The separated crystals was filtered, dried and recrystallized from ethanol to give compound 6 (Scheme 2). Color: Orange powder. Yield: 97\%. M.p.: $198-200{ }^{\circ} \mathrm{C}$. FT-IR (KBr, v, cm$\left.{ }^{-1}\right): 3316(\mathrm{NH}), 2200,2182$ (2CN), 1670 (CO), $700(\mathrm{C}-\mathrm{Cl}) .{ }^{1} \mathrm{H}$ NMR $\left(200 \mathrm{MHz}, \mathrm{DMSO}-d_{6}, \delta\right.$, ppm): $7.20-7.85\left(\mathrm{~m}, 11 \mathrm{H}, \mathrm{ArH}+\mathrm{C}_{5}-\mathrm{H}\right.$ of thiophene $\left.+\mathrm{CH}=\right)$, 11.44 (s, br, 1H, NH). MS (EI, $m / z(\%)): 389\left(\mathrm{M}^{+}, 1.2\right), 366(4.3)$, 359 (38.7), 355 (9.1), 308 (4), 267 (3.6), 256 (15.0), 224 (5.9),
200 (100.0), 174 (13.0), 163 (45.8), 135 (7.9), 128 (7.5), 99 (16.6), 89 (7.9), 67 (1.2), 60 (25.7). Anal. calcd. for $\mathrm{C}_{21} \mathrm{H}_{12} \mathrm{ClN}_{3} \mathrm{OS}$ (389.04): C, 64.70; H, 3.10; N, 10.78. Found: $\mathrm{C}$, $64.67 ; \mathrm{H}, 3.18 ; \mathrm{N}, 10.81 \%$.

\subsubsection{General procedure for the synthesis of aryl azothiophene and aryl hydrazone derivatives 8, 9, 10 and 12}

To a well-stirred cooled solution of sulphadimidine $(1.5 \mathrm{~g}, 5$ mmol) in concentrated $\mathrm{HCl}(4 \mathrm{~mL})$, a solution of $\mathrm{NaNO}_{2}(0.4 \mathrm{~g}, 5$ $\mathrm{mmol}$ in $5 \mathrm{~mL} \mathrm{H}_{2} \mathrm{O}$ ) was added drop wise. The above cooled diazonium solution was added slowly to a well-stirred solution of compound 6 (1.94 g, $5 \mathrm{mmol}), 2(1 \mathrm{~g}, 5 \mathrm{mmol})$ or $\mathbf{1 1}(1.38 \mathrm{~g}$, $5 \mathrm{mmol})$ in pyridine $(15 \mathrm{~mL})$ or $4(1.34 \mathrm{~g}, 5 \mathrm{mmol})$ in ethanol $(30 \mathrm{~mL})$ containing sodium acetate $(3.28 \mathrm{~g}, 40 \mathrm{mmol})$. The reaction mixture was stirred for $2 \mathrm{~h}$. The crude product was filtered off, dried well and recrystallized from the appropriate solvent to afford compounds 8, 9, 10 and 12, respectively (Scheme 2-4).

(E)-3-(4-Chlorophenyl)-2-cyano- $N$-(3-cyano-5- $((E)-(4-(N-$ (4,6-dimethylpyrimidin-2-yl)sulfamoyl)phenyl)diazenyl)-4phenylthiophen-2-yl)acrylamide (8): Color: Brown powder. Yield: $67 \%$. M.p.: $252-254{ }^{\circ} \mathrm{C}$. FT-IR (KBr, $\left.v, \mathrm{~cm}^{-1}\right): 3361,3226$ $(2 \mathrm{NH}), 2228,2206(2 \mathrm{CN}), 1697(\mathrm{CO}), 1488(\mathrm{~N}=\mathrm{N}), 700(\mathrm{C}-\mathrm{Cl})$. ${ }^{1} \mathrm{H}$ NMR $\left(200 \mathrm{MHz}, \mathrm{DMSO}-d_{6}, \delta, \mathrm{ppm}\right): 2.24$ (brs., $6 \mathrm{H}, 2 \mathrm{CH}_{3}$ ), 6.74 (s, $1 \mathrm{H}, \mathrm{C}_{5}-\mathrm{H}$ of pyrimidine), 7.50-8.37 (m, 14H, $\left.\mathrm{Ar}-\mathrm{H}+\mathrm{CH}=\right)$, 


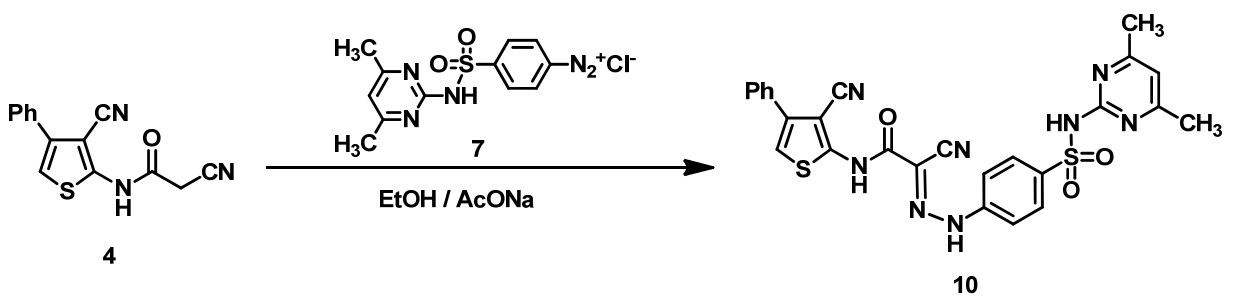

Scheme 3
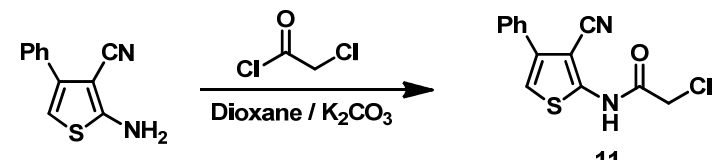

2
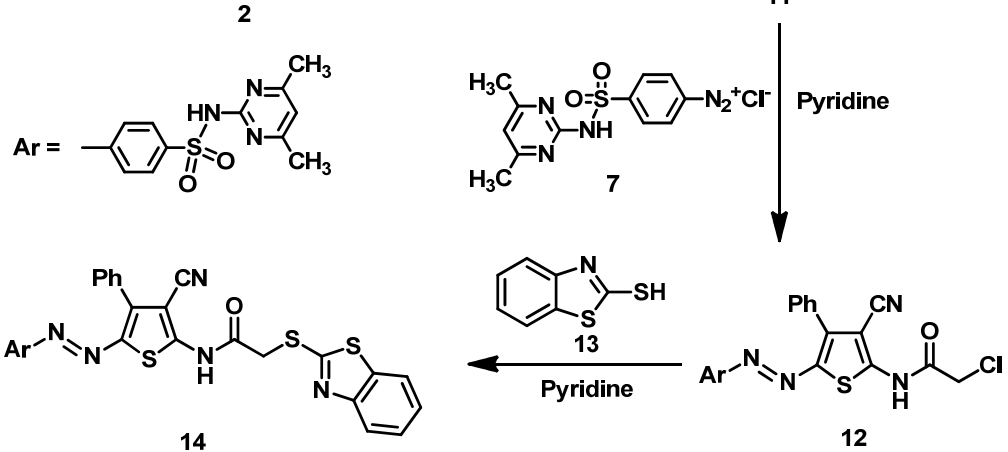

Scheme 4

11.35 (brs., $1 \mathrm{H}, \mathrm{NHCO}$ ), 12.28 (brs., $1 \mathrm{H}, \mathrm{NHSO}_{2}$ ). MS (EI, $m / z$ (\%)): $677\left(\mathrm{M}^{+}-1,0.7\right), 610$ (1.5), 570 (100.0), 556 (96.3), 551 (20.0), 497 (2.2), 430 (3.0), 357 (2.2), 322 (15.6), 279 (40.7), 214 (39.3), 200 (30.4), 167 (45.9), 148 (94.8), 140 (14.1), 110 (17), 88 (5.8), 69 (16.3). Anal. calcd. for $\mathrm{C}_{33} \mathrm{H}_{23} \mathrm{ClN}_{8} \mathrm{O}_{3} \mathrm{~S}_{2}$ (678.1): C, 58.36; H, 3.41; N, 16.50\%. Found: C, 58.40; H, 3.49; N, $16.45 \%$.

(E)-4-((5-Amino-4-cyano-3-phenylthiophen-2-yl)diazenyl)- $N$ (4,6-dimethylpyrimidin-2-yl)benzenesulfonamide (9): Color: White. Yield: $90 \%$. M.p.: $192-194{ }^{\circ} \mathrm{C}$. FT-IR $\left(\mathrm{KBr}, v, \mathrm{~cm}^{-1}\right): 3328$, 3286, $3235\left(\mathrm{NH}_{2}, \mathrm{NH}\right), 2197(\mathrm{CN}), 1452(\mathrm{~N}=\mathrm{N}) .{ }^{1} \mathrm{H}$ NMR $(200$ MHz, DMSO- $d_{6}, \delta, \mathrm{ppm}$ ): 2.23 (brs., $\left.6 \mathrm{H}, 2 \mathrm{CH}_{3}\right), 6.74\left(\mathrm{~s}, 1 \mathrm{H}, \mathrm{C}_{5}-\mathrm{H}\right.$ of pyrimidine), 7.43-8.0 (m, 9H, Ar-H), 8.90 (brs., $2 \mathrm{H}, \mathrm{NH}_{2}$ ), 11.95 (brs., $1 \mathrm{H}, \mathrm{NHSO}_{2}$ ). MS (EI, $\left.m / z(\%)\right): 492\left(\mathrm{M}^{+}+3,0.3\right), 491$ $\left(\mathrm{M}^{+}+2,0.7\right), 490\left(\mathrm{M}^{+}+1,1.6\right), 489\left(\mathrm{M}^{+}, 4.3\right), 459(0.3), 425$ (53.3), 407 (0.8), 382 (1.5), 350 (0.4), 318 (8.2), 303 (10.2), 289 (3.4), 246 (3.7), $227(6.5), 213(80.6), 198$ (33.9), 155 (16.5), 123 (100.0), 108 (22.1), 96 (33.8), 64 (59.6). Anal. calcd. for $\mathrm{C}_{23} \mathrm{H}_{19} \mathrm{~N}_{7} \mathrm{O}_{2} \mathrm{~S}_{2}$ (489.1): C, 56.43; $\mathrm{H}, 3.91 ; \mathrm{N}, 20.03 \%$. Found: $\mathrm{C}$, $56.49 ; \mathrm{H}, 3.83 ; \mathrm{N}, 20.10 \%$.

(E)-2-((3-Cyano-4-phenylthiophen-2-yl)amino)- $N^{\prime}-(4-(N-(4$, 6-dimethylpyrimidin-2-yl)sulfamoyl)phenyl)-2-oxoacetohydrazo noyl cyanide (10): Crystallization from a mixture of ethanol:benzene $(3: 1, v: v)$. Color: Yellow powder. Yield: $61 \%$. M.p.: $197-199^{\circ} \mathrm{C}$. FT-IR (KBr, v, cm $\left.{ }^{-1}\right): 3243,3235,3212(3 \mathrm{NH})$, 2230, 2197 (2CN), 1673 (CO). ${ }^{1} \mathrm{H}$ NMR (200 MHz, DMSO-d6, $\delta$, ppm): $2.25\left(\mathrm{br}, 6 \mathrm{H}, 2 \mathrm{CH}_{3}\right), 6.76\left(\mathrm{~s}, 1 \mathrm{H}, \mathrm{C}_{5}-\mathrm{H}\right.$ of pyrimidine), 7.44-8.01 (m, 10H, Ar-H, C5-H of thiophene), $11.10(\mathrm{br}, 1 \mathrm{H}, \mathrm{NH}$, hydrazone), 11.48 (brs., s, $1 \mathrm{H}, \mathrm{NHCO}$ ), 12.30 (brs., $1 \mathrm{H}, \mathrm{NNHSO}_{2}$ ). MS (EI, $m / z \quad(\%)): 407 \quad\left(\mathrm{M}^{+}-(\mathrm{HCN}+2\right.$-imino-4,5-dimethyl pyrimidine), 398 (33.1), 373 (23.5), 356 (25.5), 337 (28.5), 320 (31.3), 293 (30.6), 275 (25.8), 245 (35.6), 213 (42.5), 200 (83.6), 179 (54.6), 151 (28.1), 129 (34.1), 112 (41.7), 96 (58.7), 83 (93.4), 69 (100.0). Anal. calcd. for $\mathrm{C}_{26} \mathrm{H}_{20} \mathrm{~N}_{8} \mathrm{O}_{3} \mathrm{~S}_{2}$ (556.11): C, 56.10; H, 3.62; N, 20.13. Found: C, 56.03; H, 3.71; N, 20.24\%.
(E)-2-Chloro-N-(3-cyano-5-(C4-(N-(4,6-dimethylpyrimidin-2yl)sulfamoyl)phenyl)diazen-yl)-4-phenylthiophen-2-yl)acetamide (12): Crystallization from DMF. Color: Orange powder. Yield: 93\%. M.p.: 200-202 ${ }^{\circ} \mathrm{C}$. FT-IR (KBr, v, $\left.\mathrm{cm}^{-1}\right): 3353,3197$ (2NH), $2230(\mathrm{CN}), 1681(\mathrm{CO}), 1498(\mathrm{~N}=\mathrm{N}), 702(\mathrm{C}-\mathrm{Cl}) .{ }^{1} \mathrm{H}$ NMR $(200$ MHz, DMSO- $\left.d_{6}, \delta, \mathrm{ppm}\right): 2.23$ (br., $\left.6 \mathrm{H}, 2 \mathrm{CH}_{3}\right), 4.62\left(\mathrm{~s}, 2 \mathrm{H}, \mathrm{CH}_{2} \mathrm{Cl}\right.$ ) $6.73\left(\mathrm{~s}, 1 \mathrm{H}, \mathrm{C}_{5}-\mathrm{H}\right.$ of pyrimidine), 7.55-8.08 (m, 9H, Ar-H), 11.40 (brs., $1 \mathrm{H}, \mathrm{NHCO}$ ), 12.30 (brs., $1 \mathrm{H}, \mathrm{NHSO}_{2}$ ). MS (EI, $m / z(\%)$ ): $488\left(\mathrm{M}^{+}-\mathrm{COCH}_{2} \mathrm{Cl}, 0.1\right), 467(0.1), 411(0.3), 382(0.5), 358$ (0.2), 335 (0.2), 304 (0.9), 276 (0.4), 235 (0.5), 214 (11.2), 198 (3.9), 170 (0.9), 140 (2.0), 123 (100.0), 108 (8.8), 95 (47.0), 82 (36.3), 64 (54.7), 45 (20.3). Anal. calcd. for $\mathrm{C}_{25} \mathrm{H}_{20} \mathrm{ClN}_{7} \mathrm{O}_{3} \mathrm{~S}_{2}$ (565.08): C, 53.05; H, 3.56; N, 17.32. Found: C, 52.96; H, 3.63; N, $17.42 \%$.

\subsubsection{Synthesis of (E)-2-(benzo[d]thiazol-2-ylthio)- $\mathrm{N}$-(3- cyano-5-((4-(N-(4,6-dimethylpyrimidin-2-yl)sulfamoyl) phenyl)diazenyl)-4-phenylthiophen-2-yl)acetamide (14)}

A mixture from compound $12(2.82 \mathrm{~g}, 5 \mathrm{mmol})$ and 2 mercaptothiazole $(13)(0.83 \mathrm{~g}, 5 \mathrm{mmol})$ in pyridine $(15 \mathrm{~mL})$ was refluxed for $5 \mathrm{~h}$. The reaction mixture was left to cool and poured in ice cold water. The precipitated solid was filtered off, dried and crystallized from ethanol to give compound $\mathbf{1 4}$ (Scheme 4). Color: Black powder. Yield: 60\%. M.p.: 230-232 ${ }^{\circ} \mathrm{C}$. FT-IR (KBr, v, cm-1): 3342, 3262 (2NH), 2204 (CN), 1727 (CO), $1494(\mathrm{~N}=\mathrm{N}) .{ }^{1} \mathrm{H}$ NMR $\left(200 \mathrm{MHz}, \mathrm{DMSO}-d_{6}, \delta, \mathrm{ppm}\right): 2.24(\mathrm{br}, 6 \mathrm{H}$ $\left.2 \mathrm{CH}_{3}\right), 3.10\left(\mathrm{~s}, 2 \mathrm{H}, \mathrm{CH}_{2}\right), 6.74(\mathrm{~s}, 1 \mathrm{H}, \mathrm{C} 5-\mathrm{H}$ of pyrimidine), 7.297.99 (m, 13H, Ar-H), 11.50 (brs., 1H, NHCO), 12.48 (br., $1 \mathrm{H}$ $\mathrm{NHSO}_{2}$ ). MS (EI, $m / z(\%): 696\left(\mathrm{M}^{+}, 7.1\right), 620$ (6.3), 600 (3.8), 572 (5.7), 532 (4.3), 489 (4.7), 451 (4.0), 410 (4.5), 361 (4.9), 332 (6.1), 289 (5.9), 252 (12.3), 220 (6.5), 208 (12.7), 190 (4.7), 180 (20.8), 167 (73.7), 140 (4.0), 122 (4.7), 108 (22.7), 86 (7.7), 72 (100.0), 58 (18.0). Anal. calcd. for $\mathrm{C}_{32} \mathrm{H}_{24} \mathrm{~N}_{8} \mathrm{O}_{3} \mathrm{~S}_{4}$ 
(696.84): C, 55.15; H, 3.47; N, 16.08. Found: C, 55.23; H, 3.51; N, $16.17 \%$.

\subsection{Antioxidant activity}

\subsubsection{ABTS screening assay}

Antioxidant activity determinations were evaluated from the bleaching of ABTS derived radical cations [21]. The radical cation derived from ABTS (2,2'-Azino-bis-(3-ethyl benzo thiazoline-6-sulfonic acid)) was prepared by reaction of ABTS (60 mL) with $\mathrm{MnO}_{2}(3 \mathrm{~mL}, 25 \mathrm{mg} / \mathrm{mL})$ in $5 \mathrm{~mL}$ aqueous buffer solution $(\mathrm{pH}=7)$. After shaking the solution for a few minutes, it was centrifuged and filtered. The Absorbance (A control) of the resulting green-blue solution (ABTS radical solution) was recorded at $\lambda_{\max } 734 \mathrm{~nm}$. The absorbance (A test) was measured upon the addition of $(20 \mathrm{~mL}$ of $1 \mathrm{mg} / \mathrm{mL})$ solution of the tested sample in spectroscopic grade MeOH:buffer (1:1, v:v) to the ABTS solution. The inhibition ratio (\%) was calculated using the equation 1 .

Inhibition $(\%)=[\mathrm{A}($ control $)-\mathrm{A}($ test $) / \mathrm{A}($ control $)] \times 100$

Ascorbic acid (20 mL, $2 \mathrm{mM})$ solution was used as a standard antioxidant (positive control). Blank sample was run using solvent without ABTS (Table 1).

Table 1. ABTS antioxidant activity assay for the thiophene derivatives.

\begin{tabular}{lll}
\hline Compound & Absorbance of samples & Inhibition $\%$ \\
\hline 8 & 0.469 & 1.05 \\
9 & 0.445 & 6.11 \\
10 & 0.403 & 14.90 \\
12 & 0.452 & 4.64 \\
14 & 0.370 & 21.94 \\
Ascorbic acid & 0.048 & 89.87 \\
Control of ABTS & 0.474 & 0 \\
\hline
\end{tabular}

\subsubsection{Bleomycin-dependent DNA-damage}

The assay was done according to Aeschbach et al., [22] and Chan \& Tang [23] with minor modifications. The reaction mixture $(0.5 \mathrm{~mL})$ contained DNA $(0.5 \mathrm{mg} / \mathrm{mL})$, bleomycin sulfate $(0.05 \mathrm{mg} / \mathrm{mL})$, and $\mathrm{MgCl}_{2}(5 \mathrm{mM}), \mathrm{FeCl}_{3}(50 \mathrm{mM})$ and the samples were dissolved in DMSO to be tested at concentration $(20 \mathrm{~mL}$ of $1 \mathrm{mg} / \mathrm{mL})$. L-Ascorbic acid was used as a positive control. The mixture was incubated at $37^{\circ} \mathrm{C}$ for $1 \mathrm{~h}$. The reaction was terminated by addition of $0.05 \mathrm{~mL}$ EDTA $(0.1$ $\mathrm{M})$. The color was developed by adding thiobarbituric acid (TBA) $(0.5 \mathrm{~mL})(1 \%, w: v)$ and $\mathrm{HCl}(0.5 \mathrm{~mL})(25 \%, v: v)$ followed by heating at $80^{\circ} \mathrm{C}$ for $10 \mathrm{~min}$. After centrifugation, the extent of DNA damage was measured by the increase in absorbance at $532 \mathrm{~nm}$ (Table 2).

Table 2. Bleomycin dependent-DNA damage of thiophene derivatives.

\begin{tabular}{ll}
\hline Compound & Absorbance of samples \\
\hline 8 & 0.135 \\
9 & 0.128 \\
10 & 0.119 \\
12 & 0.141 \\
14 & 0.112 \\
Ascorbic acid & 0.097 \\
\hline
\end{tabular}

\section{Results and discussion}

\subsection{Chemistry}

The synthetic strategies adopted to obtain the target compounds are depicted in Schemes 1-4. Starting compounds 2-(1-phenylethylidene)malononitrile (1) and 2-amino-3-cyano4-phenylthiophene (2) were prepared according to the reported procedures [24,25], as outlined in Scheme 1.
Cyanoacetylation of enaminonitrile derivative 2 [25] with 3-(3,5-dimethyl-1H-pyrazol-1-yl)-3-oxopropanenitrile (3) [26] afforded 2-cyano- $N$-(3-cyano-4-phenylthiophen-2-yl)acetamide (4), the reaction proceeded according to previously reported method [27]. Furthermore, reaction of compound 4 with $p$ chlorobenzaldehyde (5) afforded corresponding arylidene derivative 6 which further coupled with sulphadimidine diazonium salt 7 in pyridine to give the corresponding aryl azothiophene derivative 8. Moreover, coupling of thiophene derivative $\mathbf{2}$ with diazonium salt $\mathbf{7}$ in pyridine afforded aryl azothiophene derivative $\mathbf{9}$ (Scheme 2).

Structures of compounds 4, 6, 8 and 9 were assessed by analytical and spectral data (IR, ${ }^{1} \mathrm{H}$ NMR and mass spectra). The IR spectra of compounds 4, 6, 8 and 9 showed absorption bands within $v 3361-3212 \mathrm{~cm}^{-1}$ due to symmetric vibrations of $\mathrm{NH}_{2}$ and $\mathrm{NH}$ groups, in addition to absorption bands within $v$ 2242-2182 cm-1 corresponding to cyano functions and absorption bands within $v 1697-1670 \mathrm{~cm}^{-1}$ due to carbonyl groups.

The ${ }^{1} \mathrm{H}$ NMR spectrum of compound 4 displayed signals at $\delta$ $4.24\left(\mathrm{~s}, 2 \mathrm{H}, \mathrm{CH}_{2}\right), 7.60-8.42(\mathrm{~m}, 6 \mathrm{H}, \mathrm{Ar}-\mathrm{H}, \mathrm{C} 5-\mathrm{H}$, thiophene), 11.12 (brs., $1 \mathrm{H}, \mathrm{NHCO}$ ) ppm. On the other hand, the ${ }^{1} \mathrm{H}$ NMR spectrum of compound 8 displayed signals at $\delta 2.24$ (brs., $6 \mathrm{H}$ ), 6.74 (s, 1H), 7.50-8.37 (m, 13H), 11.35 (brs., 1H), 12.28 ppm (brs., $1 \mathrm{H}$ ) ppm due to two $\mathrm{CH}_{3}, \mathrm{C} 5-\mathrm{H}$ of pyrimidine, aromatic, $\mathrm{NHCO}$ and $\mathrm{NHSO}_{2}$ protons, respectively. Moreover, the ${ }^{1} \mathrm{H}$ NMR spectrum of compound 9 displayed signals at $\delta 2.23$ (brs., $6 \mathrm{H}$ ), $6.74(\mathrm{~s}, 1 \mathrm{H}), 7.43-8.00(\mathrm{~m}, 9 \mathrm{H}), 8.90(\mathrm{br}, 2 \mathrm{H}), 11.95 \mathrm{ppm}$ (brs, $1 \mathrm{H}$ ) corresponding to two $\mathrm{CH}_{3}, \mathrm{C} 5-\mathrm{H}$, pyrimidine, aromatic, $\mathrm{NH}_{2}$ and $\mathrm{NHSO}_{2}$ protons, respectively.

The mass spectrum of compound $\mathbf{4}$ gave an additional evidence for structure elucidation which showed the molecular ion peaks at $m / z 269\left(\mathrm{M}^{+}+2\right), 268\left(\mathrm{M}^{+}+1\right), 267(\mathrm{M}+)$ that is in agreement with the molecular formula $\left(\mathrm{C}_{14} \mathrm{H}_{9} \mathrm{~N}_{3} \mathrm{OS}\right)$, in addition to the base peak at $m / z 200$ attributed to $\left(\mathrm{M}+-\left[\mathrm{COCH}_{2} \mathrm{CN}\right]\right)$ Also, the mass spectrum of compound $\mathbf{6}$ showed the molecular ion peak at $\mathrm{m} / \mathrm{z} 389$ that is adopted with the molecular formula $\left(\mathrm{C}_{21} \mathrm{H}_{12} \mathrm{ClN}_{3} \mathrm{OS}\right)$, in addition to the base peak at $\mathrm{m} / \mathrm{z} 200$ due to 2-amino-4-phenylthiophene-3-carbonitrile moiety. Moreover, the mass spectrum of compound $\mathbf{8}$ showed the molecular ion peak at $m / z 677\left(\mathrm{M}^{+}-1,0.7\right)$ which in agreement with the molecular formula $\left(\mathrm{C}_{33} \mathrm{H}_{23} \mathrm{ClN}_{8} \mathrm{O}_{3} \mathrm{~S}_{2}\right)$, in addition to the base peak at $m / z 570$ attributed to $\left(\mathrm{M}^{+}\right.$-(dimethylpyrimidine)) Moreover, the mass spectrum of compound $\mathbf{1 7}$ showed four molecular ion peaks at $m / z$ 492, 491, 490 and 489 corresponding to $\left(\mathrm{M}^{+}+3\right),\left(\mathrm{M}^{+}+2\right),\left(\mathrm{M}^{+}+1\right)$ and $\left(\mathrm{M}^{+}\right)$, respecttively, which are in agreement with the molecular formula $\left(\mathrm{C}_{23} \mathrm{H}_{19} \mathrm{~N}_{7} \mathrm{O}_{2} \mathrm{~S}_{2}\right)$, in addition to the base peak at $\mathrm{m} / \mathrm{z} 123$ that is related to 2 -aminodimethylpyrimidine moiety.

Moreover, coupling of cyanoacetamide derivative $\mathbf{4}$ with diazonium salt $\mathbf{7}$ in ethanol containing sodium acetate afforded the corresponding hydrazone derivative 10 (Scheme 3). Assignment of structure $\mathbf{1 0}$ was based on analytical and spectral data (IR, ${ }^{1} \mathrm{H}$ NMR and mass spectra). The IR spectrum showed absorption bands at $v 3243,3235,3212,2230,2197$, $1673 \mathrm{~cm}^{-1}$ corresponding to (3NH), (2CN) and carbonyl groups, respectively. Furthermore, the ${ }^{1} \mathrm{H}$ NMR spectrum displayed signals at $\delta 2.25$ (brs., 6H), 11.10 (brs., $1 \mathrm{H}$ ) and $12.30 \mathrm{ppm}$ (brs., $1 \mathrm{H}$ ) ppm corresponding to two $\mathrm{CH}_{3}, \mathrm{NH}$, hydrazone and $\mathrm{NHSO}_{2}$ protons, respectively. Moreover, its mass spectrum showed four molecular ion peaks at $m / z$ 407, 262, 199 and 122 corresponding to $\left(\mathrm{M}^{+}(\mathrm{HCN}+2\right.$-imino-4,5-dimethylpyrimidine $)$, 4-[(N-(4,6-dimethyl-pyrimidin-2-yl)sulfon-amide]phenyl, 2amino-4-phenylthiophene-3-carbonitrile and 2-imino-4,5dimethyl pyrimidine, respectively, in addition to the base peak at $m / z 69$ which is related to propiononitrile moiety.

Treatment of compound $\mathbf{2}$ with chloroacetyl chloride according to the previously reported method afforded the chloroacetamide derivative 11 [28] which coupled with diazonium salt $\mathbf{7}$ in pyridine to afforded the hydrazone derivative $\mathbf{1 2}$. 
<smiles>CC(C)(Cl)C(=O)Nc1sc(/N=N/Cl)c(-c2ccccc2)c1C#N</smiles>

12

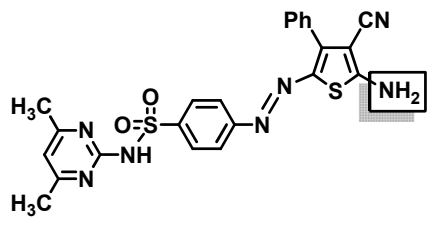

9
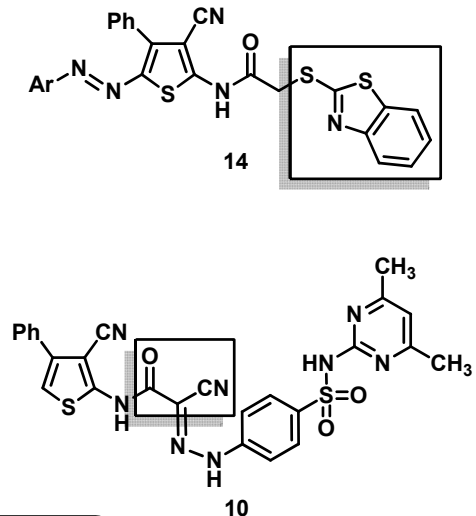

10

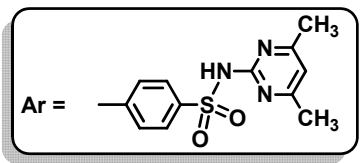

Figure 1. Structure activity relationship's (SAR's) of the more potent compounds.

Reaction of compound $\mathbf{1 2}$ with 2-mercapto benzothiazole 13 in refluxing pyridine yielded thiazole derivative 14 as outlined in Scheme 4. Assignment of compounds 12 and 14 was based on correct IR, ${ }^{1} \mathrm{H}$ NMR and mass spectral data. The IR spectra showed absorption bands within $v$ 3353-3197 and 1727-1681 $\mathrm{cm}^{-1}$ due to the stretching vibrations of $\mathrm{NH}$ and carbonyl groups, respectively, absorption bands within $v$ 1498$1494 \mathrm{~cm}^{-1}$ corresponding to symmetric vibrations of azo groups, in addition to absorption bands within v 2230-2204 $\mathrm{cm}^{-1}$ are attributed to cyano groups of the coupler moieties. The ${ }^{1} \mathrm{H}$ NMR spectrum of compound 12 displayed signals at $\delta 2.23$ (brs., 6H), 4.62 (s, 2H), 6.73 (s, 1H), 7.55-8.08 (m, 9H), 11.40 (br, $1 \mathrm{H}), 12.30(\mathrm{br}, 1 \mathrm{H}) \mathrm{ppm}$ due to two $\mathrm{CH}_{3}, \mathrm{CH}_{2} \mathrm{Cl}, \mathrm{C} 5-\mathrm{H}$, pyrimidine, aromatic, $\mathrm{NHCO}$ and $\mathrm{NHSO}_{2}$ protons, respectively. On the other hand, the ${ }^{1} \mathrm{H}$ NMR spectrum of compound $\mathbf{1 4}$ revealed signals at $\delta 2.24$ (brs., $6 \mathrm{H}), 3.10(\mathrm{~s}, 2 \mathrm{H}), 6.74(\mathrm{~s}, 1 \mathrm{H})$, 7.29-7.99 (m, 13H), 11.50 (brs., 1H), 12.48 (brs., 1H) ppm due to two $\mathrm{CH}_{3}, \mathrm{CH}_{2}, \mathrm{C}-\mathrm{H}$, pyrimidine, aromatic, $\mathrm{NHCO}$ and $\mathrm{NHSO}_{2}$ protons, respectively. The mass spectrum of compound 12 showed the molecular ion peak at $m / z \quad 488$ which is equivalence to $\left(\mathrm{M}^{+}-\mathrm{COCH}_{2} \mathrm{Cl}\right)$, in addition to the base peak at $\mathrm{m} / z 123$ which is assigned to 2-imino-4,5-dimethylpyrimidine moiety. Moreover, the mass spectrum of compound 14 showed the molecular ion peak at $m / z 696\left(\mathrm{M}^{+}\right)$which is in agreement with the molecular formula $\left(\mathrm{C}_{32} \mathrm{H}_{24} \mathrm{~N}_{8} \mathrm{O}_{3} \mathrm{~S}_{4}\right)$.

\subsection{Biological activity}

\subsubsection{Antioxidant activity assay}

The antioxidant activities for five thiophene derivatives were evaluated as reported method by Lissi et al. [21]. The results outlined in Table 1 showed clearly that the investigated compounds exhibited weak activities.

\subsubsection{Bleomycin-dependent DNA-damage}

Five thiophene derivatives were selected for bleomycindependent DNA-damage screening (Table 2). Damage of DNA in the presence of a bleomycin-Fe complex has been adopted as a sensitive and specific method to examine potential pro-oxidant agents [29]. If the tested samples are able to reduce the bleomycin- $\mathrm{Fe}^{3+}$ and $\mathrm{Fe}^{2+}$ to bleomycin- $\mathrm{Fe}^{2+}$, DNA degradation in this system will be stimulated, resulting in a positive test for pro-oxidant activity. Degradation of DNA is accompanied by the formation of a product similar to malondialdehyde (MDA).
L-Ascorbic acid as a reducing agent can reduce $\mathrm{Fe}^{3+}$ to $\mathrm{Fe}^{2+}$. The results outlined in Table 2 showed that all of the investigated compounds exhibited weak activities.

By comparing the results obtained of antioxidant of the compounds reported in this study to their structures, the following structure activity relationship's (SAR's) were postulated:

(i) Cyanoacetamide $\mathbf{1 0}$ is more potent than thiophene $\mathbf{9}$ which may be attributable to presence of cyanoacetamide moiety.

(ii) Compound $\mathbf{1 4}$ is more potent than chloroacetamide 12 which may be due to replacement of chlorine atom by mercaptothiazole moiety (Figure 1 ).

\section{Conclusion}

The objective of the present study was to synthesize and evaluate the antioxidant activity of some novel sulphadimidine incorporating thiophene moiety with the hope of discovering new structure leads serving as antioxidant agents. The data clearly showed that all of the investigated compounds exhibited weak anti-oxidant activities.

\section{Acknowledgement}

We deeply appreciate the assistance of Dr. A. Abass, PharmacognosyDepartment, Faculty of Pharmacy, Mansoura University, Mansoura, Egypt for screening of the Biological activities of the tested compounds

\section{References}

[1]. Okafor, E. C.; Adiukwu, P. U. ; Uzoukwu, B. A. Synth. React. Inorg. Met. Org. Chem. 1993, 23, 97-111.

[2]. Tantawy, A.; Goda, F.; Abdelal, A. M. Chin. Pharm. J. 1995, 47, 37-45.

[3]. Ojha, A. C.; Jain, R. Pol. J. Chem. 1982, 56, 1553-1560.

[4]. Ferguson, G. N.; Valant, C.; Horne, J.; Figler, H.; Flynn, B. L.; Linden, J.; Chalmers, D. K.; Sexton, P. M.; Christopoulos A.; Scammells, P. J. J. Med Chem. 2008, 51(19), 6165-6172.

[5]. Nikolakopoulos, G.; Figler, H.; Linden, J.; Scammells, P. J. Bioorg. Med. Chem. 2006, 14, 2358-2365.

[6]. Gutschow, M.; Kuerschner, L.; Neumann, U.; Pietsch, M.; Loser, R. Koglin N.; Eger, K. J. Med. Chem. 1999, 42(26), 5437-5447.

[7]. Gutschow, M.; Neumann, U. J. Med. Chem. 1998, 41(10), 1729-1740.

[8]. Koebel, R. F.; Needham L. L.; Witt Blanton, C. J. Med. Chem. 1975, 18 192-194.

[9]. Huybrechts, L.; Buffel, D.; Freyne, E.; Hoornaert, G. Tetrahedron 1984 $40(13), 2479-2485$ 
[10]. Mubarak, A. T.; El-Sonbati, A. Z.; El-Bindary, A. A. Chem. Pap. 2004, 58, 320-323.

[11]. El-Bindary, A. A.; El-Sonbati, A. Z. Polish J. Chem. 2000, 74, 615-620.

[12]. Al-Sarawy, A. A.; El-Bindary, A. A.; El-Sonbati, A. Z.; Makpel, M. M. Polish J. Chem. 2006, 80, 289-295.

[13]. El-Sonbati, A. Z.; El-Bindary, A. A.; Ahmed, R. M. Spectrochim. Acta A 2002, 58, 333-339.

[14]. El-Sonbati, A. Z.; El-Bindary, A. A.; Mabrouk, E. M.; Ahmed, R. M. Spectrochim. Acta A 2001, 57, 1751-1757

[15]. El-Sonbati, A. Z.; Diab, M. A.; El-Shehawy, M. S.; Moqbal, M. P. Spectrochim. Acta A 2010, 75, 394-405.

[16]. Gouda, M. A.; Abu-Hashem, A. A. Arch. Pharm. (Weinheim) 2011, 344(3), 170-177.

[17]. El Bialya, S. A. A.; Gouda, M. A. J. Heterocyclic Chem. 2011, 48(6), 12801286.

[18]. Hamama, W. S.; Berghot, M. A.; Baz, E. A.; Gouda, M. A. Arch. Pharm. (Weinheim) 2011, 344 (11), 710-718.

[19]. Hamama, W. S.; Zoorob, H. H.; Gouda, M. A.; Afsah, E. M. Pharm. Chem. J. 2011, 45(2), 118-124.

[20]. Gouda, M. A.; Berghot, M. A.; Baz, E. A.; Hamama, W. S. Med. Chem. Res. 2012, 21, 1062-1070.

[21]. Lissi, E. A.; Modak, B.; Torres, R.; Esocbar, J.; Urzua A. Free Radical Res. 1999, 30(6), 471-477.

[22]. Aeschbach, R.; Loliger, J.; Scott, B. C.; Murcia, A.; Butler, J.; Halliwell, B.; Aruoma, O. I. Food Chem. Toxicol. 1994, 32(1), 31-36.

[23]. Chan, T. Y.; Tang P. L. J. Pineal Res. 1996, 20, 187-191.

[24]. Tumer, F.; Ekinci, D.; Zilbeyaz, K.; Demir, U. Turk. J. Chem. 2004, 28, 395-404.

[25]. Gewald K. Chem. Ber. 1965, 98(11), 3571-3577.

[26]. Ried, W.; Schleimer, B. Angew. Chem. 1958, 70, 164-69.

[27]. Gorobets, N. Y.; Yousef, B. H.; Belaj, F.; Kappe. C. O. Tetrahedron 2004, 60(39), 8633-8644.

[28]. Soliman, A. M.; Khodairy, A.; Ahmed E. A. Phosphorus Sulfur 2003, 178 (4), 649-665.

[29]. Gutteridge, J. M. C.; Rowley, D. A.; Halliwell B. Biochem. J. 1981, 199, 263-265. 